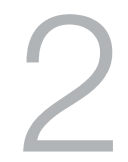

\title{
Strategic Studies in a Changing World
}

\section{T.B. Millar}

This essay was previously published in the 40th anniversary edition. It is reprinted here in its near original format.

At the beginning of his excellent book of memoirs, Dean Acheson quotes the 13th-century Spanish monarch Alphonso X, who said that if he had been present at the creation of the universe, he would have had some sound advice to give the Creator for a rather better ordering of things. Having been present at the creation of the Strategic and Defence Studies Centre (SDSC), I cannot absolve myself of any responsibility, but looking at its achievements over these 25 years (1966-91), I can only wonder at the size and strength of the oak that has sprung from the acorn we then planted.

I joined The Australian National University (ANU) when I was in London in July 1962, and arrived in Canberra by train in October. Canberra railway station in those days was, I believe, the original edifice, built out of weatherboards 50 years earlier and painted government brown. It was an appropriate station for a one-horse country town; it was not particularly appropriate for the national capital, but the national capital was only in the early stages of moving from the one-horse country town it had been to becoming the city we now have. The lake bed had been scraped, and the lake was beginning 
to fill. Those crude barrack-like structures that were to house so much of the Department of Defence had not yet been built. Major government departments, including Defence, had only recently moved to Canberra, with Defence being housed alongside External Affairs in that sunken battleship known as the Administration Building. Mr R.G. Menzies had been prime minister for the previous 13 years, and looked like going on being prime minister for ever, so divided was the Labor Party. The Liberals had had a narrow squeak at the 1961 election, but God was now back in his heaven and all was right with the world.

Well, perhaps not all. Australia still had a battalion and some aircraft in Malaya, although the Emergency there had been declared over. Sukarno was proclaiming the New Emerging Forces, which were to take over from the forces of neo-colonialism. The ferment in IndoChina, which had forced the end of French rule there, was continuing, despite the arrangements made at the 1954 Geneva Conference. The administration of President John F. Kennedy in the United States had put its foot into the quagmire of Vietnam, believing that American power, efficiency and goodwill, from an impeccably antiimperial background, would settle the mess left by the departing colonial French, and strike a blow for freedom and against communism in the process. Although the term had not gained current usage, Australian security was based on the concept of 'forward defence'; i.e. that Australia should be defended, largely by powerful friends, as far forward of the mainland and with as little cost to Australia as possible. An idea of the size of the cost was the provision in 1962 at American request of a mere 30 instructors to help train the South Vietnamese Army.

I joined the Department of International Relations, at that time housed in a building on Liversidge St. One day in mid-1963 I had a visit from Arthur Lowndes, a member of the then Australian Broadcasting Commission $(\mathrm{ABC})$ and president of the Australian Institute of Political Science (AIPS). He told me that AIPS held a summer school in Canberra every January, and the 1964 conference was due to discuss Australian defence and foreign policy. He was looking for someone to give a paper on 'Australia's defence needs'. I told him that I was not the one. I had left the regular army as a young captain in 1950 and the Civilian Military Force (CMF) as a major in 1953. I was singularly ill-informed on defence questions. The area of my research at ANU 
was international institutions, especially the United Nations and the Commonwealth. I suggested he try one of the generals. He said that no serving officer would be allowed to give the paper, and they had tried everyone else they could think of. So, faute de mieux, I took it on, and the whole course of my life was changed. SDSC's 25 th anniversary conference in 1991 stemmed in a direct line from Lowndes' visit and his powers of persuasion.

Writing the paper was a considerable challenge to me. Despite having served eight years in the regular army, I am not by nature a military man; so I consulted everyone I could find. I remember going to Defence and talking with Gordon Blakers and Sam Landau, who were then (I think) assistant secretaries. I had a list of about 20 questions. The two men were friendly and polite, but were able, or prepared, to answer almost none of my questions, on grounds of military security. Defence, in the government's view, was not a matter for public inquiry or debate; the public should simply accept the Defence provisions that the Australian Government, in its superior wisdom and knowledge, provided. I remember asking for the outline of the pentropic division, into which the Australian Army was in the process of being reorganised. They replied that this was classified information. I pointed out that if I was still in the CMF I would be giving lectures on this subject. 'Yes,' they said, 'and you would be subject to military discipline.'

During those few months that I spent writing that paper, I learned my first lesson about getting information which the establishment, for whatever honourable or dishonourable reason, wants to conceal from the public: you don't go to the top, for they won't tell you. You don't go to the bottom, because they never know more than a tiny bit of the picture, and even that is often distorted. You go to the bright people in the middle, the ones who have had some experience of the system, want to see it improved but cannot do much about it themselves. I spoke to everyone who would speak to me, and gradually put together a paper full of splendid sentiments, pungent comments, and proposals for brilliant initiatives. Then one day, as I was reading over the mellifluous phrases with more than a hint of self-satisfaction, a terrible thought came to me: if you were the minister for defence, would you do the things you so fervently advocate? And I realised 
that I would not necessarily do them. So, for good or ill, I rewrote the paper and gave it at the conference at the Australia Day weekend in January $1964 .^{1}$

Reading it again years later, it seems to me to have not been a bad paper. Bernard Shaw said that he liked to quote himself as it added spice to his conversation. I do not claim his literary felicity, but I believe that most of what I said at that conference still stands up. Among other things, I said that Australia is primarily and ultimately responsible for its own security; that we must produce security if we are to consume it - we must pay our insurance premiums, our club fees. I recommended that we should not be involved in operations in both Malaya and Vietnam simultaneously, but if we were to be able to make a significant contribution in the region we had no alternative to introducing some form of conscription. I was critical of the pentropic organisation, which was splendid in theory but unwieldy in operation, and of the decision to buy the F-111 aircraft, still at that stage on the drawing boards. I recommended that we have a joint services staff college, and a lot of other things. Several eminent people took me to task for my proposals. Malcolm Fraser, then a rising young Liberal backbencher, could not understand why I was not better informed - I only had to ask, he said. General Wilton, Chief of the General Staff, called me in and told me that I didn't know what I was talking about as regards the pentropic organisation, and he caused an article to be written and published in the Australian Army Journal, entitled 'King of the Jungle or Paper Tiger?'2 A few months later the pentropic organisation was abandoned, so presumably it was not the king of our jungle. Air Chief Marshal Scherger, Chairman of the Chiefs of Staff Committee, called me in and told me that I didn't know what I was talking about regarding the F-111. He quoted to me from Fortune Magazine; I quoted to him from Aviation Week and Space Technology. It turned out to be a good aircraft, but of course we did not get it until long after the time when our political masters had thought it might be needed.

1 The paper was subsequently published as 'Australia's Defence Needs' in John Wilkes (ed.), Australia's Defence and Foreign Policy (Melbourne: Angus \& Robertson, for the Australian Institute of Political Science, 1964), chpt 3.

2 Directorate of Military Training, 'King of the Jungle or Paper Tiger?', Australian Army Journal, No. 179, Apr. 1964, pp. 5-9. 
The summer school generated considerable public debate on defence matters, more than at any time since World War II. I like to think that my contribution, together with that of the Minister for External Affairs Sir Garfield Barwick, US Assistant Secretary of State Roger Hilsman, and others, helped to make it a more informed debate than it would otherwise have been.

Shortly after the summer school, I took off for my first visit to Asia as an academic. At Canberra airport that afternoon I purchased an evening paper and discovered that the HMAS Melbourne had sunk the HMAS Voyager, with considerable loss of life and substantially reducing our naval capacity. While I was in India, as I recall, I received a letter from Peter Ryan, the energetic director of Melbourne University Press (MUP). He suggested I write a book on defence, which I did when I returned, and it was published by MUP the following year. ${ }^{3}$ As far as I know, it was the first substantial monograph on the subject written by any Australian.

This time, as I did my research, more doors were open to me. Events in Indonesia, Malaysia and Vietnam brought a heightened public awareness of defence questions, and serving officers and civil servants (especially in the Department of External Affairs, as distinct from Defence) were more ready to talk to me off the record. I remember giving an address in Sydney on the defence of Papua and New Guinea. In preparing for the address, I was concerned at the extent of Indonesian military activity in West New Guinea, and talked to a senior officer in External Affairs about it. He got out the relevant file, and quoted to me the intelligence estimate, which I could only use as background and without attribution, but which was quite a low figure - a thousand or two, as I recall. Flying up to Sydney a few days later to give the talk, I found myself seated next to a senior Defence official. I asked him the same question, but he replied that he was unable to comment. Trying for a reaction, I said I had seen (which I had) an estimate of 30,000 Indonesian troops - a wildly exaggerated figure, of course. He would not respond, but I saw him wrestling with his conscience all the way to Sydney. He then gave me a lift into the

3 T.B. Millar, Australia's Defence (Carlton: Melbourne University Press, 1965). A second edition was published in 1969. 
city in his Commonwealth car and, as we neared our destination, he said to me: 'You know that figure of Indonesians you suggested?' 'Yes', I replied. 'It's too big', he said.

Writing a book about defence was a very different thing from giving a paper at a conference. I had never written a book of any kind, and I had none of the techniques, but it was great fun nevertheless and, following the AIPS venture and the considerable public speaking I was called on to do as a result, I had a sense - probably an exaggerated one - that what I was writing was important, and that I had to get it right because, in some way, the security of the nation was involved. Many friends and old comrades in the Services were only too delighted to have me ride their hobby horses, and I was not always as discriminating an equestrian as I should have been; but the book was well received, and proved a boon to the Service staff colleges, which had never had an Australian textbook to work from. One point on which I was criticised was the cover. The dust jacket of the first edition showed Australia with a series of menacing red arrows above it, pointing down. In fact I had nothing to do with the cover. Ryan was a good editor and became a warm friend, but he did not believe in showing authors the dust jackets of their work, in case they objected - as I certainly would have done. The cover was changed for the second edition four years later.

The book was published in late April 1965. Just before copies were shipped off to bookshops, Menzies announced that Australia would be sending a battalion to Vietnam. It was too late to revise the text but, at Ryan's suggestion, I wrote a postscript that was printed separately and inserted as a slip inside the cover. I do not have a copy of the slip, and do not remember exactly what I wrote, except for the last sentence, which was: 'We are paying the penalty for years of neglect.' A bit dramatic, perhaps, but largely true, as it would have been true of many other occasions in our history. Rudyard Kipling's poem on the infantry soldier Tommy Atkins epitomises the British and Australian attitudes to defence:

For it's Tommy this, an' Tommy that, an' 'Chuck him out, the brute!' But it's 'Saviour of 'is country' when the guns begin to shoot. ${ }^{4}$

4 Rudyard Kipling, 'Tommy', The Penguin Poetry Library (London: Penguin Books, 1977), p. 161. 
Our participation in the Vietnam War stimulated public debate on defence matters. It is now largely forgotten how widespread was the support for the decision to enter the war in the early stages, and how easily the government managed to get the precedent-breaking legislation of conscription for overseas service through parliament and the country. My own feeling is that Menzies' almost entirely erroneous description of the Vietnam War as representing China thrusting down between the Indian and Pacific Oceans, played on the 'yellow peril' syndrome that was latent within the Australian consciousness, and was a big factor in winning public acceptance for the war. I remember commenting adversely on his analysis at a meeting of the Australian Institute of Public Administration, and being told by a senior public servant in the audience that Menzies knew a lot more about the matter than I did. Asked in parliament to comment on something I had written, Menzies referred to me as 'some scribbler in Canberra'. If I ever get around to writing my memoirs, I am thinking of calling them 'Memoirs of a Scribbler in Canberra'.

We all no doubt have our memories of these heady days. I felt it was unwise for Australia to get involved in two wars simultaneously - in Malaysia and Vietnam - but once the decision was taken to go to Vietnam I broadly supported it, on the basis of paying our club fees, and also because I felt the people of South Vietnam were entitled to live out their lives in safety. I remember taking part in the first teachin on Vietnam in Canberra, in the Childers St hall, at which the author Morris West addressed the packed audience in highly emotional tones. The meeting started at about $7.30 \mathrm{pm}$ and went on until the early hours of the morning. I spoke some time after midnight, when the crowd had not noticeably diminished, such was the public interest. I recall saying that nowhere had a communist government taken over by democratic means. Bruce MacFarlane, who was in the audience, shouted out: 'What about Czechoslovakia?' To which I replied, emulating the Duke of Wellington: 'If you believe that, you can believe anything.' He was not pleased with me. A good many academics became involved in the public debate on defence and security questions, centred on Vietnam - I am thinking of people like Bruce Miller, Arthur Burns, Ian Wilson, Arthur Huck, Max Teichmann, Joe Camilleri, Glen Barclay, Harry Gelber, Hedley Bull, Peter Boyce, Brian Beddie, Jamie Mackie, 
Greg Clark, Peter King, and Patrick FitzGerald, among others; and journalists like Peter Hastings, Denis Warner, and Bruce Grant; and I also wrote and broadcasted about it.

One ANU academic with a continuing entrepreneurial interest in defence questions was Arthur Burns, formerly of the Department of International Relations and then of the Department of Political Science in the Research School of Social Sciences. Burns set up a Defence Studies Project at ANU, with the encouragement of Professor Leicester Webb and with some support from the Australian Institute of International Affairs (AIIA). The project organised two conferences, one on nuclear dispersal in Asia and the Indo-Pacific region, and one on Commonwealth responsibilities for security in the Indo-Pacific region, in 1965 and 1966 respectively. The proceedings of both were published in reduced format. ${ }^{5}$ Burns had a strong interest in the setting up of the Centre, and its continuing activities.

The Centre came about in the following way. One day, in early 1966, Bruce Miller, Professor of International Relations at ANU, told me of the relatively new idea of creating centres or units within the university, separate from or inside departments. It was a way of attracting outside funds, and of concentrating academic activity on a field of interest. Accordingly, at Miller's suggestion and with his help, I worked up a proposal for a centre to study strategic and defence questions. Sir John Crawford was Director of the Research School of Pacific Studies (RSPacS), and I talked it over with him. He undertook to try to get funds from the Ford Foundation for the project, and did so. Miller, who was very supportive, unfortunately went on study leave at a crucial time, and George Modelski became acting head of the Department of International Relations. I did not feel he was as sympathetic to the project as Miller, and the upshot was that, when it was established, it was given its own organisation separate from International Relations. In those days, heads of departments in the research schools went on study leave for one year in four, and I did not feel that I could take the risk of having the new project in unfriendly hands for such a high proportion of the time, especially its inaugural year. I may have been

5 Nina Heathcote (ed.), Nuclear Dispersal in Asia and the Indo-Pacific Region (Canberra: ANU, for the Defence Studies Project and the Australian Institute of International Affairs, 1965); and A.L. Burns \& Nina Heathcote (eds), Commonwealth Responsibilities for Security in the IndoPacific Region (Canberra: ANU, for the Defence Studies Project and the Australian Institute of International Affairs, March 1966). 
doing Modelski an injustice, but I knew he regarded me as dangerously right wing. The proposal was discussed at a faculty board meeting, but Crawford took the decision to create the Centre, with an advisory committee and me as executive officer (as the headship was then called), although I retained my position in International Relations, at that time being a senior fellow. The object of the Centre was to advance the study of Australian, regional, and global strategic defence issues.

Before getting the Centre underway, I went to Britain and the United States in order to see how they managed these things. In London I talked to Alastair Buchan at the Institute for Strategic Studies (ISS), to Michael Howard, Professor of War Studies at King's College, London, and to a private luncheon at the Royal Institute of International Affairs, Chatham House, to which Foreign Office and Defence Ministry officials were invited. In the United States I spoke with a number of the defence think tanks. None of them provided a clear model for us to copy. The various institutes had access to substantial private funding, which (despite Ford Foundation generosity) we could not feel confident of, on any continuing basis. King's College had a Department of War Studies, as a formal academic activity of the university. We were not ready for that, and we were not into military history, which was a substantial part of the King's College curriculum.

We gave much thought to the question of access to, and use of, classified information. Crawford was strongly opposed to seeking such access. I suppose I had the rather naive view at that time that classified information was likely to be more accurate than unclassified information. This view underwent modification the longer I stayed in Canberra. Formally, we were not entitled to receive anything classified Restricted or above but, in fact, as Des Ball was to find to his benefit, there are a lot of people holding positions of confidence who are prepared to spill the beans in private, without attribution. The problem is of course that, without access to the same or equally good alternative sources, you cannot always tell the quality of the beans. The British and American institutes obviously had formalised as well as informal access to classified information.

In Australia, we had no tradition of academics having access to confidential government information in the social sciences, almost no tradition of academics writing on defence matters, and only very little experience of academics writing on foreign affairs, the AIIA 
providing the shining exception. Australian academics writing on political matters tended to be left of centre. This did not cause problems during the short periods of Labor government but, apart from the Depression, and the period 1941-49, Australia until 1972 was almost continuously under conservative rule. The Australian political system, irrespective of the party in power, has tended to be obsessed by secrecy, and conservative governments especially so. The combination of these factors made it difficult for anyone in academia to write on defence without arousing that paranoia with which our politics is so generously endowed.

In the formation of SDSC, we took the decision that we would not seek access to classified information, but that we would be prepared to have comments, from friendly officials, without obligation on either side, on what we wrote. At ANU we had developed good relations with people in the Commonwealth Department of External Affairs, largely because of an initiative taken by Miller, with the help of Sir Alan Watt (a former secretary of External Affairs, who was a visiting fellow in the Department of International Relations) in founding in 1963 what was initially called the 'Third Monday Club'. This was a group of senior diplomats and academics with an interest in external matters, who met over dinner in the Scarth Room at University House on the third Monday of each month. One of us would open the batting on a matter of current interest, and there would be general discussion, entirely off the record. At first the officials approached this rather gingerly, but they came to see that none of us had horns, or an obviously direct line to the Kremlin, and some very good discussions resulted. It was good also from the university's point of view, as our group contained people from several disciplines. Later I was to found what we called the 'Foreign Affairs Club', with relatively senior officials from Defence, External Affairs, Prime Minister and Cabinet, Trade and so forth, and a range of academics, who met over lunch at the old Hotel Canberra, with a guest speaker. These meetings had the additional benefit that - to my astonishment - they introduced officials from different departments to each other. I had not appreciated how compartmented the public service was.

By these means, the ignorance, suspicion and distrust that had existed to a varying degree between the public service and academia were significantly (if selectively) broken down. On our side, of course, we had to watch out for a different danger: that we would become the 
captive of the establishment, sharing their assumptions and accepting their conclusions. A university that does not have a tradition of dissent is not a proper university. Having Crawford as director had many benefits, but he never quite left the public service, psychologically.

It took several years for the Centre and its work to be generally accepted within ANU as a proper academic activity. I soon realised that some of my colleagues, and academics in other universities, regarded me as (to quote the communist jargon of the time) a 'running dog of the imperialists', or of the Central Intelligence Agency (CIA), or an agent of the Defence Department, but in any case rather disreputable. I am grateful that I did not have the kind of disruption that Bob O'Neill was subjected to later on, but people did say and write some very rude things about me, often with a grain of truth in them, to make them stick. Miller, Crawford, and Oskar Spate who succeeded Crawford as director of RSPacS, were all supportive and, indeed, protective, but I think it was not until well after the Vietnam War was over that the Centre was accorded general respectability. We were of course conscious of the problems, and laboured to ensure that all reasonable points of view were presented at our gatherings, not out of selfprotection but because we believed that that was what universities were about.

I remember being rung one day by the $\mathrm{ABC}$, which was arranging a television debate on a planned moratorium march. 'We want you to take the position opposed to the march', the gentleman said. I said that, whereas I thought it likely that my views would be significantly different from those of some of the marchers, I believed strongly in the right of people, whatever their beliefs, to engage in such public protests, and that I thought that it was to protect such rights that we had armed forces. 'Well you'd be no good to us,' said the ABC man.

The Australian Labor Party came to realise that the Centre offered a forum for them to express their dissenting views, but interestingly enough they also came to realise that we provided an expertise on which they could draw. Later, when they became the government, they invited me to chair the Committee of Inquiry into the Citizen Military Forces and the Army Cadets. ${ }^{6}$

6 See Committee of Inquiry into the Citizen Military Forces [Chaired by T.B. Millar] Report, Mar. 1974 (Canberra: Australian Government Publishing Service). 
The name of the Centre was a bit of a mouthful. I tried out various simpler combinations, like 'Defence Studies' or 'Security Studies' and O'Neill (when he took over in 1971) wrestled with the same problem. But no other title fitted exactly what we wanted to study, which was a combination of strategic questions and the problems of national defence. So 'Strategic and Defence Studies Centre' it became, and remained.

To start with, all I had was a secretary. Then, with Ford Foundation funds, we were able to appoint a research fellow. This was Ian Bellany, a nuclear physicist who had worked on arms control and disarmament questions with the British Foreign Office. He was to prove an excellent colleague, and wrote a valuable book that Sydney University Press published in 1972, Australia in the Nuclear Age: National Defence and National Development? ? $^{7}$ an was a very effective acting head of the Centre when I went on study leave in 1968-69. At the end of his time with us, he took a post at Lancaster University, where he held a chair in international relations.

The Centre was small, but active. Our first conference was in September 1967, on the implications for Australia of Britain's decision to withdraw from east of Suez. In 1968, in conjunction with Chip Wood, director of ANU Press, we launched the Canberra Papers on Strategy and Defence. Alex Hunter, an economist, wrote the first paper, on oil in Australia's defence strategy, ${ }^{8}$ and Geoffrey Jukes, ${ }^{9}$ Jim Richardson, ${ }^{10}$ and Ian Bellany ${ }^{11}$ followed. These constituted the beginning of the sizable library of literature on strategic and defence matters for which the Centre has been responsible. O'Neill instituted working papers (which provided quick publication of seminar papers) and reference papers, as well as greatly extending the publication of Canberra Papers.

7 See Ian Bellany, Australia in the Nuclear Age: National Defence and National Development (Sydney University Press, 1972).

8 Alex Hunter, Oil Supply in Australia's Defence Strategy, Canberra Papers on Strategy and Defence No. 1 (Canberra: ANU, 1968).

9 Geoffrey Jukes, The Strategic Situation in the 1980s, Canberra Papers on Strategy and Defence No. 2 (Canberra: ANU, 1968).

10 J.L. Richardson, Australia and the Non-Proliferation Treaty, Canberra Papers on Strategy and Defence No. 3 (Canberra: ANU, 1968).

11 Ian Bellany, An Australian Nuclear Force, Canberra Papers on Strategy and Defence No. 4 (Canberra: ANU, 1968). 
In 1968 we had our first international venture, at a conference in Wellington on Australian-New Zealand defence cooperation. By this time the formidable Hedley Bull had joined the Department of International Relations, and the Advisory Committee of SDSC. Victoria University in Wellington provided us with the venue for the conference, and New Zealand academics and officials took part. Australia was less well represented at the official level, due to government caution. The proceedings of this conference were also published, ${ }^{12}$ and this became the custom.

In 1969 Watt retired as director of AIIA, and I was appointed in his place. By this time I was a professorial fellow in International Relations, as well as being in charge of the Centre. I realised, and I think other people did also, that these three activities were rather more than one person could adequately handle. Around this time $\mathrm{O}^{\prime} \mathrm{Neill}$ joined International Relations, from the staff of Duntroon, and I asked him whether he would be interested in taking over the Centre. O'Neill initially said 'No', but Bull and I persuaded him to let his name go forward for it. I duly resigned in 1971 and $\mathrm{O}^{\prime}$ Neill took over. I believed then, as I do now, that this was the best thing I could have done and one of the best things I have ever done. SDSC has never looked back from that time.

O'Neill's first major - and vital - achievement was to get the Centre within the ANU budgeting system. The Ford Foundation funds ran out, and ANU or other funding was necessary if SDSC was to survive. The existence of the Advisory Committee, which we had set up at the beginning under Crawford's watchful eye, was a help. He (as director) was the first chairman, and this principle has continued to be practised, but for Advisory Committee members we have called on other departments within Pacific Studies and other research schools including Social Sciences and Physical Sciences. After a time, defence specialists from outside ANU came to be members of the Advisory Committee. I tried to interest External Affairs and Defence in the idea, but both wanted to remain detached. No representation meant no responsibility. Nevertheless, Sir James Plimsoll, who was Secretary of External Affairs at the time, was especially helpful, while Defence was kindly disposed if cautiously inclined. It later sought to have

12 T.B. Millar (ed.), Australian-New Zealand Defence Co-operation (Canberra: ANU, 1968). 
a representative on the Advisory Committee, but by then the committee opposed the idea. I am sure that the range of interests represented in the Advisory Committee and the high calibre of the members have served SDSC well, especially in having the Centre firmly established as a respectable part of ANU and funded within the ANU budget. Here I should pay tribute to the support given to the Centre in all sorts of ways by the business manager of the joint schools, Peter Grimshaw.

One of the Centre's first activities stemming from a relationship with Defence was an exercise in futurology, which the Army asked us to undertake. We had a series of meetings of an ad hoc group from several disciplines within ANU trying to peer 10 and more years ahead to make rational guesses as to what kind of world Australia - and the Australian Army - might find itself in. Due to the fact that my secretary of the time could not easily read my writing, this group became known as the Forecastry Group. I do not know to what purpose our conclusions were put, but it was an interesting exercise and I think the Army found it worthwhile. (They could at least blame us if they got it wrong!)

O'Neill was head of SDSC from 1971 to 1982 and, during that time, he extended and expanded its activities considerably, making it one of the most significant and respected institutions of its kind. He developed excellent relations with government, while maintaining the Centre's independence as an academic institution. In his first couple of years, SDSC was shaken increasingly by public opposition to the Vietnam War, which found its echoes or indeed its voice in academia. One visiting American lecturer was prevented from speaking, and gangs of student thugs threatened to smash up the SDSC library. Now that I am retired, I feel I can say that some ANU senior officers displayed a regrettable lack of intestinal fortitude in dealing with these disrupting elements, and the normal activities of the Centre suffered. It had been our custom to give briefings to visiting groups from the Royal College of Defence Studies in London, and the US National Defense College. SDSC was required to do this off-campus.

$\mathrm{O}^{\prime}$ Neill sought and obtained funds from the Ford Foundation. The small library resources capacity was extended, with a full-time librarian/ research assistant. A visiting fellows program was initiated, bringing academics and occasionally officials from various parts of Asia and the Pacific for specific research. In 1978 this was supplemented by funds 
from the Department of Defence for a Defence Visiting Fellowship, occupied either by a serving officer or a civil servant. In 1984, under a separate agreement with the Navy, a naval fellowship was established. In 1985 Defence agreed to fund two visiting fellowships per year for academics to carry out advanced research on strategic and defence problems. Exchange arrangements were also made with the Institute of International Studies in Beijing, and the Institute on Global Conflict and Cooperation of the University of California, in 1983 and 1985 respectively. The formal staff of the Centre were also increased from time to time so that, by 1991, it had six academic posts - a professor as head (Paul Dibb), a special professor (Des Ball), four senior research fellows or research fellows, four visiting fellows with at least a oneyear contract, plus six supporting staff. At any one time there were maybe another two short-term visiting fellows. There was also a parttime research assistant and a part-time clerical officer.

Although still comparatively small by some international standards, this is of course the largest centre of its kind in Australia, or indeed in the southern hemisphere, and its output and influence as a national institution stand comparison with any non-governmental centre anywhere in the world. It may seem surprising that this small country of Australia, which over recent years has become marginal to most international events, should have produced so significant a centre. I see this in some ways as parallel to what has happened in the Australian departments of Foreign Affairs and Trade (DFAT) and of Defence, whereby the considerable professionalism built up over the 30 years of international tension following World War II in which Australia was involved are now devoted less to national survival under threat and the reform of international society than to the application of energetic thought to appropriate pressure points - a kind of political acupuncture.

Yet SDSC, as an academic institution, is rather less - and more than that: less, in that it does not carry governmental weight, and more in that it has an ongoing educational role, demonstrated not only through the annual conferences, the massive list of publications, the participation of SDSC staff in public lectures, broadcasts, giving evidence to parliamentary committees, contributing to government inquiries, lecturing to and advising the various Defence colleges and so forth, but also in the graduate program that has developed since 1984, first by having doctoral students, and then through the Master's 
and graduate diploma courses (originally funded by the MacArthur Foundation in Chicago). Students in 1991 came from within Australia, from China, Japan, South-East Asia, and the south-west Pacific.

One aspect, which began in my time, was greatly extended under $\mathrm{O}^{\prime}$ Neill's headship, and continued under Ball's, was the development of studies concerning the defence of Australia. These became especially relevant after the end of the Vietnam War, when it was obvious that there had to be a seachange in Australian attitudes to regional security. With the departure from the region of Australia's 'great and powerful friends', old concepts of 'forward defence' were no longer relevant.

I do not want to write the Centre too high, but the fact is that, for those Australians inside or outside the Defence establishment who are interested in defence matters, SDSC supplies an opportunity for acquiring information and for contributing to the public debate that nowhere else provided.

O'Neill left SDSC in 1982 to become the highly successful director of IISS. Much against my better judgement, I took over the headship again for a couple of years.

I was fortunate, and grateful, to be able to hand SDSC over to someone who had already made a major contribution to the Centre's work, and to the international strategic debate, especially in nuclear missile questions. I hope Des Ball will forgive me if I mention my recollection - and recollections are not invariably accurate - of a tall young man looking rather like an early version of the prophet Moses with sharp eyes peering out from a formidable facial foliage, with bare feet, walking the Coombs corridors. This was the recent university medallist in economics beginning his controversial career in strategic studies with a PhD under Bull's tutelage. Ball was born to controversy as the sparks fly upwards, holding the supportable view that the government was obsessed with secrecy and that many of the things it wanted to keep to itself were the proper and indeed necessary subject of public and informed debate. Being from an earlier generation, with a military background, I was occasionally concerned that some of Ball's revelations might in fact be better not revealed, in the national interest, but I had no doubt of the integrity of his research and its findings. SDSC continued to prosper and increase under his guidance and no one can today doubt that he has filled a unique niche in the public debate on defence matters. I was also delighted when Dibb, 
a very old friend who has made major contributions to the study and analysis of defence matters, both within the establishment and within ANU, was appointed to replace Ball as head of SDSC.

I here mention three people who have played, in their own ways, vital parts in the work and success of SDSC: Colonel Jol Langtry, who looked after the administrative aspects for many years; Billie Dalrymple, who was secretary to $\mathrm{O}^{\prime} \mathrm{Neill}$, to me, and to Ball; and Elza Sullivan, who ably performed so much of the Centre's word processing from which its considerable list of publications have ensued. In his submission to the review of the Centre in April 1987, Ball wrote that SDSC is 'one of the most successful academic enterprises in the University'. This view is widely held at ANU.

I believe that centres concerned with peace research must be included in any consideration of 'strategic studies'. During the period of my second headship of the Centre, the Labor Government under Bob Hawke, and with Bill Hayden as Minister for Foreign Affairs and Trade, expressed an interest in establishing peace studies at ANU. I tried to get them subsumed within the Centre, but I fought a losing battle against the Advisory Committee (which did not give me the support I expected), the Minister for External Affairs (who wanted to be seen to be doing something about peace), and the board of the Institute of Advanced Studies (which bought the notion that a centre devoted to the studying of peace would somehow bring more peace about). (As Kenneth Boulding once said, this was equivalent to saying that a centre devoted to the study of garbage disposal would lead to an increase in the quantity of garbage to be disposed of.) As is now history, the government decided to establish a separate Peace Research Centre (PRC) within RSPacS in 1984 with a continuing grant from DFAT. My one contribution in this area lay in appointing Andrew Mack as senior research fellow in the SDSC, from which he went on to the even greater heights of head of PRC and then to the chair in International Relations.

The PRC was organised very much on the lines of SDSC, though of course with an emphasis on studying conflict resolution and reduction more than conflict itself. In 1991, PRC had an advisory committee also chaired by the Director of the Research School of Pacific and Asian Studies (RSPAS) and with representation from other departments and the SDSC at ANU, other universities, DFAT, and the Law Reform Commission. It had a head, three senior research fellows, two research 
fellows, five research assistants, and two other staff. Under Mack's energetic direction, PRC became an important member of the family of such centres around the world. It ran seminars and conferences, produced the quarterly journal Pacific Research, and published a number of major monographs, and an astonishing number of working papers. It also had a valuable resources centre.

The introduction of peace studies at the University of Sydney grew out of staff members mainly within the Department of Government, especially Peter King, and a staff-student committee. Given initial financial support from the University of Sydney, a centre was launched by the Minister for Defence in May 1988 and named the Centre for Peace and Conflict Studies (CPACS). Its declared aim was to 'promote the study of conflict prevention and resolution and the long term conditions for peace'. CPACS held seminars, lectures and conferences, including a seminar series on 'Deconstructing Deterrence', the papers from which were subsequently published as Beyond Deterrence. ${ }^{13}$ A three-day workshop on conflict resolution was run in cooperation with the Law Council of Australia. There was a steady flow of international visitors to CPACS. The University of Sydney provided funds for the first 15 months, covering a half-time secretary and maintenance, plus a grant to purchase an American archive.

Deakin University has had an interest in strategic studies since its inception in 1977, stemming in good measure from the interests of Francis West, teaching courses that included them at undergraduate and graduate level within the School of Social Sciences. From 1991, Deakin offered higher degree courses specifically in this area: a Diploma in Defence Studies and a Master's degree in the same subject. The courses were designed to appeal especially (but by no means only) to serving officers of the armed forces, who received credit for any staff college or other professional military qualifications. Deakin is a leader in the field of 'distance education' in Australia, and it is thus especially useful for officers, public servants, or others who want to study in this area without leaving their normal work environment.

When the Australian Defence Force Academy (ADFA) went into the business of graduate study, it was natural that it would establish a program in defence or strategic studies. The Australian Defence

13 Beyond Deterrence: A Multifaceted Study (Centre for Peace and Conflict Studies, University of Sydney, 1989). 
Studies Centre (ADSC) was accordingly set up in 1987 to promote research and study in all aspects of Australian defence, to support and assist postgraduate and honours degree students at ADFA working in the relevant fields, and to cooperate with other organisations involved in the study of Australian defence. It provides for part-time as well as full-time study. The Master of Defence Studies course is open to civilian as well as military personnel. The choice of subjects includes politics, history, geography, civil engineering, computer science and economics. ADSC has seminars and conferences, and produces monographs. In 1991 it ran a major conference on naval power in the Pacific. It has a steady flow of visiting fellows from within or outside Australia. It has close relations with the study centres established within the three Services: the Air Power Studies Centre, the Maritime Strategic Studies Project, and the Directorate of Army Studies; it also provides consultants to work on study projects identified by the Services. In addition to these three centres, the Australian Defence Force Warfare Centre was established in late 1990 and is based on the old Australian Joint Warfare Establishment at Williamtown.

One member of the university strategic studies/peace studies centres was the Indian Ocean Centre for Peace Studies, sponsored by the University of Western Australia (UWA) and Curtin University, and funded jointly by the federal Department of Employment, Education and Training and DFAT. Drawing on both universities, and multidisciplinary in character, the centre focused on arms control and the geopolitical setting; environmental, resources and developmental issues; and social justice, equity and the law. The centre stemmed from UWA and Murdoch University academics' long interest in Indian Ocean affairs, and Curtin's Centre of Indian Ocean Regional Studies.

Apart from the various departments of politics, government, or at the Department of International Relations at ANU, and individual academics such as Harry Gelber at the University of Tasmania, Fedor Mediansky at the University of New South Wales, and Joe Camilleri at La Trobe University, the only other Australian university in 1991 with a centre whose activities border or touch on strategic, defence or peace issues is Griffith, especially the Centre for the Study of AustraliaAsia Relations (CSAAR). Among its other, more politically oriented studies and publications are the reports of international conferences on Indochina and the prospects for conflict resolution there. In 1991 
CSAAR held the major conference 'Security in the Asia-Pacific Region: The Challenge of a Changing Environment', which I had the privilege of attending.

Outside the Defence establishment and the universities, the only institution as at 1991 with even a hint of 'think tankery' was the 'private, non-profit-making' Pacific Security Research Institute in Sydney set up in April 1989, with Owen Harries as President and former diplomat David Anderson as Executive Director. Funded in roughly equal proportions by a number of leading Australian companies and three American foundations, its purpose was to undertake research and stimulate public discussion on foreign, defence and economic policy issues in the Asia-Pacific region with particular reference to Australian national interests. It published several papers in a series called Australia and Tomorrow's Pacific, a paper on Australia's response to the Gulf War (1990-91), and papers delivered at two conferences.

Separate again from any of these institutions and from government is the Royal United Services Institute of Australia, catering largely to serving and retired officers, who have used their state branches and publication of a journal for several decades to keep up a professional debate on the major strategic and defence issues of the day. The Naval Institute is a similar body, with an accent on maritime matters.

Having been out of Australia for much of the six years prior to 1991, I hope that I have not overlooked the work of any institution or individual during that period.

Looking back between 1966 and 1991, it is hard to imagine we are in the same capital, or even the same country. I remember a seminar we ran on the future of the aircraft carrier, with a paper from a student. Around the table in Seminar Room B in the H.C. Coombs Building were something like a dozen admirals and senior captains, none of whom was prepared to say a word on the subject or even to ask a question. Well, at least they were there. Today we would find them actively participating in the discussion, with perhaps one of them giving the paper. The number of books and journal articles on strategic and defence questions has grown exponentially. Strategy and defence are now respectable subjects of academic courses and research. The media have become much better informed - certainly they have a much greater range of expertise to call on. 
It is impossible to know what impact this growth of public information and discussion has had on specific policies of government. A number of the things I recommended in that 1964 AIPS paper were implemented not, I believe, because I recommended them, but rather because they were sensible things to do, although sometimes governments will only do sensible things if the public urges them. At times, SDSC seemed to have a more obvious influence. I am thinking here particularly of the 1976 conference on the future of tactical air power in Australia, which was reported at the time to have influenced the government over the principles of selection for a replacement of the Mirage fighters, and also of the Centre's contribution to the Regular Officers Development Committee at around the same time. Certainly, the report of the CMF Inquiry committee, ${ }^{14}$ and Paul Dibb's review of Australia's defence capabilities $^{15}$ - although neither was an SDSC activity as such were important parts of the decision-making process. Between 1966 and 1991, the quality and the quantity of debate, and academic contributions to it, changed beyond recognition.

It is tempting to believe that this splendid development has come at a time when it is less needed than ever, with the end of the Cold War, and the reduction of tension within our region. I think that is a profound mistake. Although there is no enemy at our gate, many parts of the world are in a state of tension or even conflict, some of which could spill over into areas or situations affecting Australia. I am not in the business today of drawing up scenarios for the possible deployment of the Australian Defence Forces, as I did in 1964. But perhaps if there had been more people then with a serious professional interest in these matters, Australia might have gone in different directions. And, as I have said many times over these intervening years, threats to our nation and people and way of life can develop more rapidly than we can build up the forces and the philosophies and the expertise to cope with them. At a time when the forces, for economic reasons, are being inevitably decreased, it is heartening to find that the philosophies and the expertise of strategy and defence studies are being given far more and far better attention than at any period in our peacetime history.

14 T.B. Millar, Committee of Inquiry into the Citizen Military Forces (Canberra: Australian Government Publishing Service, 1974).

15 Paul Dibb, Review of Australia's Defence Capabilities, report to the Minister for Defence (Canberra: Australian Government Publishing Service, 1986). 
This text is taken from A National Asset: 50 Years of the Strategic and Defence Studies Centre, edited by Desmond Ball and Andrew Carr, published 2016 by ANU Press, The Australian National University,

Canberra, Australia. 